\title{
Climate change impact assessment in hotels: methodology and adaptation strategies for high quality hotels
}

\author{
A. Pinto ${ }^{1}$, M. Bernardino ${ }^{2}$, A. Silva $\operatorname{Santos}^{1} \&$ F. Espírito Santo ${ }^{2}$ \\ ${ }^{1}$ LNEC, Portugal \\ ${ }^{2} P M A$, Portugal
}

\begin{abstract}
Hotels are buildings with major specific energy and water demands per occupant, due to high levels of services and comfort provided and expectation from tourists, meaning that they could be one of the building types more vulnerable to changes in climate. Usually high occupancy rates of hotels happen in summer, for beach and city hotels, increasing the vulnerability to climate change. Projected changes in mean and extreme temperature and precipitation over the Mediterranean region, in particular over mainland Portugal, will be likely to intensify the well-known asymmetries in the Portuguese climate, with more intense heat waves and with longer duration. This paper presents the methodology followed in project AdaPT AC:T to assess the vulnerability of hotels to climate change and the impact of some adaptation strategies.

Keywords: climate change, energy efficiency, hotels, adaptation, mitigation.
\end{abstract}

\section{Introduction}

Buildings are responsible for nearly $40 \%$ of fossil fuel consumption and greenhouse gas emissions [1]. In the buildings sector, hotels have a high energy and water consumption per capita, namely the four and five star hotels due to the high comfort standards and services provided that require energy and water. In Lisbon and Algarve hotels could have an energy consumption of 10 to $100 \mathrm{kWh}_{\mathrm{pe}} / \mathrm{g}$.n and water consumption of 50 to $2000 \mathrm{l} / \mathrm{g} . \mathrm{n}$, compared with 3 to $4 \mathrm{kWh}$ pe/p.n and 100 to $150 \mathrm{l} / \mathrm{p} . \mathrm{n}$ in homes [2].

In Mediterranean countries tourism has an important impact in the economy $6 \%$ of GDP in Portugal - and its importance is increasing in recent years with 
more tourist and new hotels (figure 1). The greater occupancy rates of hotels occur in summer (figure 2), for beach and city hotels, opposing other type of building that are closed in the summer or have lower occupancies, such as schools. This simultaneous occurrences of larger occupancies, warmer weather and large energy and water consumptions makes hotels one of the building types more vulnerable to stress due to climate change in Mediterranean region. It's well known that tourists have a high adaptive capacity to shift their destination, while hotels and other infrastructures should be resilient and assure the quality of their service.

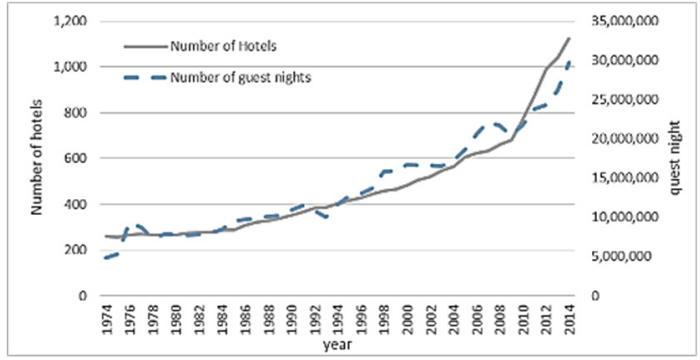

Figure 1: Number of hotels and guest nights (data from INE).

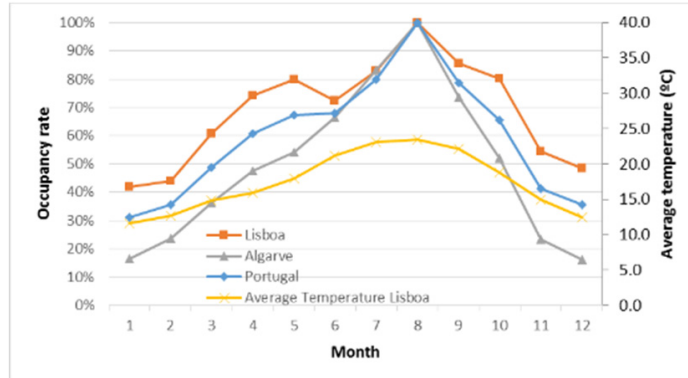

Figure 2: Average occupancy rate of Portuguese hotels and average temperature (data from INE and IPMA).

In the severe heat wave of 2003 [3], numerous vulnerabilities of buildings were revealed, namely $1 / 4$ of food refrigeration systems were unable to cope with the heat, very significant portion of accommodation proved uncomfortable and the air conditioning systems were inefficacies due to problems in power supply services and loss of efficiency. In less stringent weather condition, the weather has a direct impact on energy consumption namely for air conditioning [2], reinforcing the requirement for energy and water efficient hotels and Nearly Zero Energy Hotels $[1,4]$ to mitigate the greenhouse gases emission and has a strategy to adapt buildings to climate change.

Li et al. [5] review the impact of climate change in energy consumption in the built environment in different climate zones and states that in zones with heating and cooling needs, the magnitude of cooling will increase and will be comparable 
to the reduction in heating. This response is aligned with other studies $[6,7]$ developed with reference buildings. For hotels in Greece [8] a decrease in heating demand of $50 \%$ and an increase of $248 \%$ in cooling demand is expected; while in Portugal, Santos et al. [6] estimate electricity consumption of 250 to $465 \mathrm{kWh} / \mathrm{g} . \mathrm{n}$, and an increase of $30 \%$ in energy consumption for cooling.

To reduce the greenhouse gas emission and Europe dependency from fossil fuel, new buildings should comply with energy efficiency requirements [1] and new construction after 2020 should be NZEB. There is numerous building with poor thermal insulation and equipment with low performance and below the actual minimum requirements. This emphasises the importance to assess the impact of climate change for new and existing constructions.

This paper will present the methodology and results from the climate change vulnerability assessment of one high quality hotel in Lisbon, concerning the energy demand. This assessment is supported by a detailed analysis with high resolution (hourly and daily) observed and simulated data, under heat waves/hot days/hot nights, identifying the vulnerable aspects of hotels and the adaptation potential.

\section{Methods}

\subsection{General aspects}

Climate change impact assessment and the development of adaptation strategies requires the study of hotels vulnerabilities and risk to climate variables, taking account the exposure factors, the sensitivity of the building to climate and nonclimate factors (figure 3). To assess the potential impact of climate change, were developed climate scenarios (section 2.2) and a detailed building energy model supported by an audit. The non-climate factors were assessed as strategies to control building and systems use. It was not studied the plausible change in the pattern of hotel use/seasonality, namely an increase in spring and winter season. In this article the exposure factor adopted is the rising temperature that could increase cooling demand, water consumption in cooling towers.

Hotel sensitivity to climate variables and the effectiveness of adaptation strategies is assessed in a reliable way with the validated building energy model that reflects the hotel thermal characteristics, electromechanical systems, control strategies and occupancy.

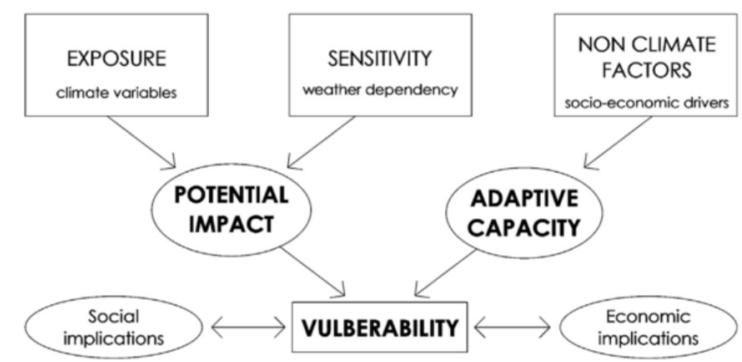

Figure 3: Climate impact and vulnerability assessment scheme [9]. 


\subsection{Exposure: observed data and climate scenarios}

According to IPCC [10], warming of the climate system is unequivocal, and since the 1950s, many of the observed changes are unprecedented over decades to millennia. The globally averaged combined land and ocean surface temperature data as calculated by a linear trend, show a warming of 0.85 [0.65 to 1.06$]^{\circ} \mathrm{C}$ over the period 1880-2012, when multiple independently produced datasets exist, 0.89 [0.69 to 1.08$]^{\circ} \mathrm{C}$, over the period 1901 to 2012 , and about $0.72[0.49 \text { to } 0.89]^{\circ} \mathrm{C}$ over the period 1951-2012 when based on three independently-produced data sets.

Global surface temperature change for the end of the 21 st century is likely to exceed $1.5^{\circ} \mathrm{C}$ relative to 1850 to 1900 for all RCP scenarios except RCP2.6. It is likely to exceed $2^{\circ} \mathrm{C}$ for RCP6.0 and RCP8.5, and more likely than not to exceed $2^{\circ} \mathrm{C}$ for RCP4.5.

The observational studies for mainland Portugal indicate a wide-spread increase of warm extremes in all seasons, in particular in spring and summer, with more intense heat waves and with longer duration, and concurrently a significant increase in the frequency of hot days and tropical nights [11]. Other studies show that in Portugal there was a significant positive trend, particularly after 1976, in heat waves, summer days, warm spells and warm nights and days, while a negative trend was observed in cold extremes, particularly in winter [12].

Focusing only on temperature data for Lisbon in the period 2008-2015 8 heat waves occurred ( 5 in the spring, 2 in summer and 1 in autumn) with a duration of between 7 and 8 days. Heat waves observed in summer occurred in July in 2013 and June 2015, with the simultaneous occurrence of warm nights and tropical nights. It should be noted other warm periods (for example, August 2009, July and August 2010, June 2013) with very hot days (maximum temperature above $35^{\circ} \mathrm{C}$ ), warm nights and tropical nights.

To assess the impact of actual weather variability and extremes in hotel energy performance the last 8 years' weather data is used and also test reference years for Lisbon. With those data, the morphing method [13] was used to generate climate scenarios with the HadCM3 Global Circulation Model (GCM) for year 2080 and for the emission scenario RCP8.5, since with other emission scenarios and smaller periods the impact of climate change is expected to be small [2]. In figure 4 a comparison of Lisbon average temperature for the year 2010 is shown and epw file [14] and with the morphed files for scenarios RCP8.5 to 2080. The average annual temperature for the year 2010 and epw2013 file are the same: $17.0^{\circ} \mathrm{C}$. The
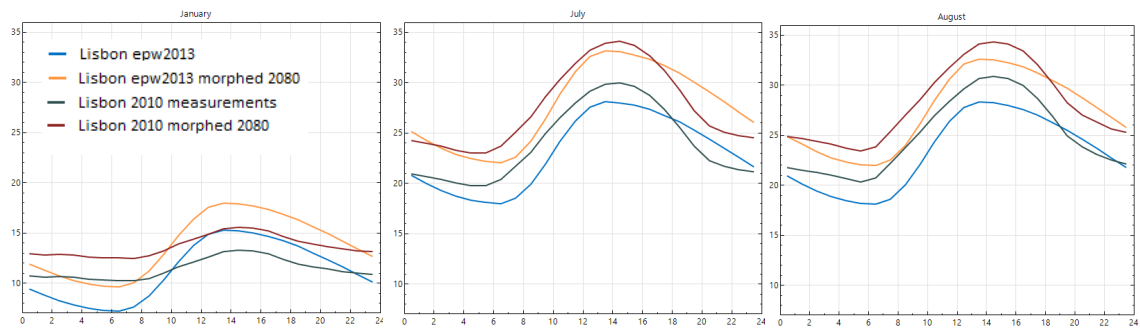

Figure 4: Lisbon average temperature: measures data, epw and scenarios. 
CC scenario 2010 have an annual average temperature $2.7^{\circ} \mathrm{C}$ higher and August average temperature is $3.2^{\circ} \mathrm{C}$ higher. The shape of temperate curve in the epw generated weather data and 2010 measured data is different. Due to hot days in July and august 2010 have a maximum monthly average temperate in July and August higher than the epw file $\left(28.1^{\circ} \mathrm{C}\right.$ in August vs. $27.6^{\circ} \mathrm{C}$ in July). To analyse the CC impact in section 3.3 the weather data of 2010 is chosen instead of the generated epw 2013 data file, because it has measured values for Lisbon and include "extremely" hot days.

\subsection{Sensitivity and non-climate factors}

An audit is required to collect data from building fabric, electromechanical systems, occupancy and use of energy and support the development of the detailed energy model of the hotel. In a simplified way the relation between heating and cooling load is given by (1), that is reasonable to assess the monthly energy consumptions (figure 5) [2]. To assess the impact of climate variability and extremely hot days, it's required to use building energy models with hourly data.

$$
Q_{\text {heat }}=\sum\left[\sum A \cdot U+\rho \dot{V} c_{p}\right]\left(T_{i}-T_{o}\right)-\eta\left(G_{\text {solar }}+G_{\text {int ernal }}\right)
$$
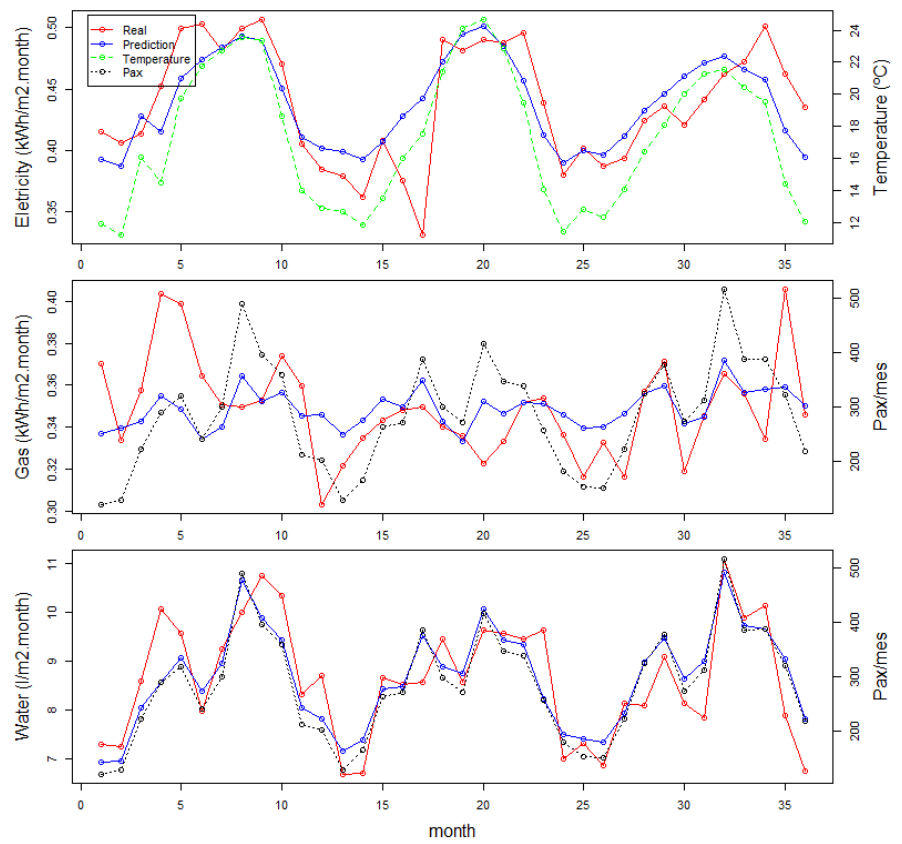

Figure 5: Monthly energy and water consumption by heated/cooled floor area relation with average temperature and occupancy. 
The energy consumption in major areas of the hotel (kitchen, laundry, restaurant, SPA, bedrooms, lifts), were measure with data logger during 15 days, 5 minutes' time step. It was also measure the energy consumption of central plant air conditioning systems (chillers, cooling towers, pumps and fans), boiler efficiency, pipes and ducts thermal insulation. To assess the energy performance, it was also measured the outdoor environment conditions and indoor temperatures in: four bedrooms, corridors, lobby, restaurants and offices.

\subsection{Adaptation and mitigation strategies}

To improve hotel resilience to climate change several strategies are identified $[15$, 16]. In this paper, the results for the following strategies will be presented (table 1): passive solution like the use of external shading, high reflective coatings, free cooling and thermal insulation; HVAC improvement, namely chiller heat recovery, high efficiency chillers, pipe thermal insulation.

Table 1: Mitigation and adaptation strategies.

\begin{tabular}{|l|c|}
\hline & New solutions \\
\hline Thermal performance and passive behaviour: & \\
\hline $\begin{array}{l}\text { Increased thermal resistance of wall and roofs } \\
\text { external shading device } \\
\text { overhang }\end{array}$ & $\mathrm{U}_{\text {window }}=3.0 / 2.0 ; \mathrm{U}_{\text {wall }}=0.4 ; \mathrm{U}_{\text {roof }}=0.3$ \\
\hline $\begin{array}{l}\text { Solar shading of windows: } \\
\mathrm{g}=0.25 \\
\mathrm{~g}=0.5, \alpha=45^{\circ}\end{array}$ \\
\hline Additional natural ventilation to promote free cooling & 2 ach in bedrooms \\
\hline Electro-mechanical systems & $20-25^{\circ} \mathrm{C}$ \\
\hline Set-points & $\mathrm{EER}=5.5(\mathrm{Class} \mathrm{A})$ \\
\hline High efficiency mechanical cooling & Yes \\
\hline Chiller with heat recovery & $2 \mathrm{~m}^{2} / \mathrm{bedroom}$ \\
\hline Solar collector for Domestic Hot Water & $\eta=98 \%(\mathrm{Class} \mathrm{A++)}$ \\
\hline Boiler & $25 \mathrm{~mm}$ \\
\hline Thermal insulation of pipes & $150 \mathrm{l} / \mathrm{gn}$ \\
\hline $\begin{array}{l}\text { Water conservation with low water use fittings and occupant } \\
\text { training, room services management/cleaning }[17]\end{array}$ & yes \\
\hline Water conservation through rainwater collection & $2 \mathrm{~m}^{2} / \mathrm{bedroom}$ \\
\hline Photovoltaics in SW facade and roof & \\
\hline
\end{tabular}

Units of $\mathrm{U}: \mathrm{W} / \mathrm{m}^{2} . \mathrm{K}$.

\section{Case study}

\subsection{Building}

The study building is a high quality existing hotel in Lisbon. In table 2, hotel dimensions and thermal characteristics of the building envelope are shown. The hotels all have public zones with air conditioning. The cooling is provided by chillers $(\mathrm{EER}=4.3)$ with open cooling towers, which delivers cold water to the fan coils of the bedrooms, and the air handling units of meeting rooms, restaurants, lobby and other major spaces. The indoor pool has a dedicated dehumidifier unit. The heating and the hot water is provided by two natural gas boilers $(\eta=90 \%)$. 
Table 2: Hotel characteristics.

\begin{tabular}{|c|c|c|c|c|c|c|c|c|c|c|c|c|}
\hline \multirow{2}{*}{\begin{tabular}{|c|}
$\begin{array}{c}\mathbf{A}_{\text {floor hotel }} / \\
\mathbf{n}_{\text {bedrooms }}\end{array}$ \\
$48 \mathrm{~m}^{2}$ \\
\end{tabular}} & $\begin{array}{c}\text { Pool / } \\
\text { n } \\
\text { bedrooms }\end{array}$ & \multicolumn{2}{|c|}{$\begin{array}{l}\text { A }_{\text {envelope }} / \\
\text { Volume }\end{array}$} & WWR & \multirow{2}{*}{\begin{tabular}{|c}
$\begin{array}{c}\mathbf{U}_{\text {wall }} \\
\mathbf{W} / \mathbf{m}^{2} . \mathbf{K}\end{array}$ \\
1.0
\end{tabular}} & \multirow{2}{*}{\begin{tabular}{|c|}
$\rho_{\text {sol wall }}$ \\
0.60
\end{tabular}} & \multicolumn{2}{|c|}{$\begin{array}{c}\mathbf{U}_{\text {roof }} \\
\mathbf{W} / \mathbf{m}^{2} . K\end{array}$} & \multicolumn{2}{|c|}{ Ssol roof } & $\begin{array}{l}\mathbf{U}_{\text {window }} \\
\mathbf{W} / \mathbf{m}^{2} . \mathbf{K}\end{array}$ & $\begin{array}{c}\text { Solar } \\
\mathrm{g}\end{array}$ \\
\hline & $0.25 \mathrm{~m}^{2}$ & & .11 & $46 \%$ & & & 1 & & 0.1 & & $3.0 / 2.0$ & $0.5 / 0.25$ \\
\hline \multicolumn{13}{|c|}{ Hotel architecture: space/hotel floor area } \\
\hline Rooms & Laundry & $\mathrm{Re}$ & aurant & Kitchen & $\begin{array}{c}\text { Meeting } \\
\text { rooms }\end{array}$ & SPA & $\begin{array}{r}\text { Ind } \\
\text { Pc }\end{array}$ & & $\begin{array}{l}\text { Lobb } \\
\text { corric }\end{array}$ & & Parking & Other \\
\hline $33 \%$ & $1 \%$ & & $\%$ & $1 \%$ & $8 \%$ & $1 \%$ & & & $21 \%$ & & $7 \%$ & $25 \%$ \\
\hline \multicolumn{13}{|c|}{ Hotel HVAC systems: } \\
\hline $\begin{array}{l}\text { Chillers } \\
\left(\mathrm{W} / \mathrm{m}^{2}\right)\end{array}$ & \multicolumn{2}{|c|}{$\begin{array}{l}\text { Boilers } \\
\left(\mathrm{W} / \mathrm{m}^{2}\right)\end{array}$} & \multicolumn{2}{|c|}{$\begin{array}{l}\text { Pumps } \\
\left(\mathrm{W} / \mathrm{m}^{2}\right)\end{array}$} & $\begin{array}{l}\text { Fans } \\
\left.N / \mathrm{m}^{2}\right)\end{array}$ & \multicolumn{2}{|c|}{$\begin{array}{c}\text { Cooling } \\
\text { tower } \\
\left(\mathrm{W} / \mathrm{m}^{2}\right)\end{array}$} & \multicolumn{2}{|c|}{$\begin{array}{c}\text { Light } \\
\left(\mathrm{W} / \mathrm{m}^{2}\right)\end{array}$} & \multicolumn{2}{|c|}{$\begin{array}{c}\text { Equipment } \\
\left(\mathrm{W} / \mathrm{m}^{2}\right)\end{array}$} & $\begin{array}{l}\mathrm{e}_{\text {pipe insulation }} \\
\text { (mm) }\end{array}$ \\
\hline 43 & 113 & & 2 & & 3.2 & 0.6 & & & 5 & & 6 & 15 \\
\hline
\end{tabular}

\subsection{Indoor environment and use}

The temperature in several spaces of the hotel was measured. In figure 6 the temperature of four bedrooms and two restaurants is shown. Despite the variation, the average temperature was nearly $23^{\circ} \mathrm{C}$, in accordance with the neutral temperature EN 15251, and below a typical $25^{\circ} \mathrm{C}$ agreed to calculate de cooling energy [14] and EN 15251. In the analyses of real building it will be used the narrow comfort temperatures $21-23^{\circ} \mathrm{C}$. In table 3 , the average illuminance level for some spaces is shown, which is quite low in bedrooms. The light density power is acceptable ([14] requires LDP of 3.4 in kitchens and 3.8 in Lobby). In fact, in several spaces the retrofit to LED lamps is already done. It was measured the air flow rate in some air handling units, and it's estimated an average flow of 1 ach.

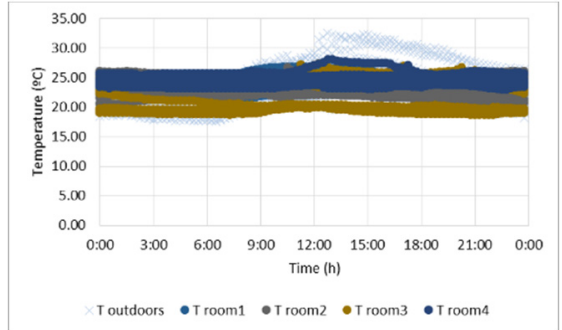

(a)

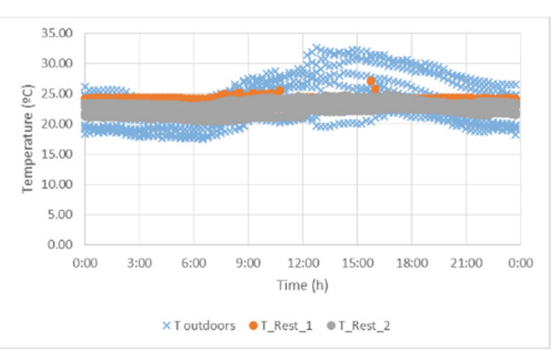

(b)

Figure 6: Temperature measurement. (a) bedrooms; (b) restaurants.

Table 3: Artificial light systems.

\begin{tabular}{|l|c|c|c|c|}
\hline & Bedroom & Lobby & Restaurant & Kitchen \\
\hline $\mathrm{E}_{\mathrm{m}}(\mathrm{lx})$ & 90 & 105 & 180 & 240 \\
\hline $\mathrm{LDP}\left(\mathrm{W} / \mathrm{m}^{2} / 1001 \mathrm{x}\right)$ & 4.8 & 3.0 & 1.2 & 2.8 \\
\hline
\end{tabular}

With the measurement of energy consumption and temperatures and information collected it was developed for each space the density and pattern of occupancy, light, equipment and air conditioning use. The hotel supplied the average monthly room occupancy and guest nights (figure 7). 


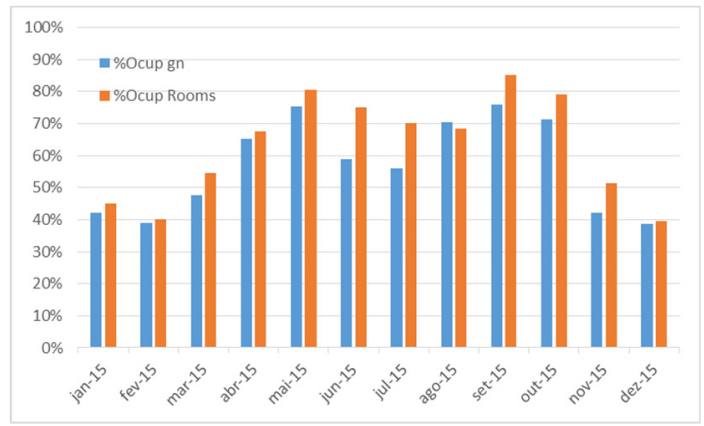

Figure 7: Monthly occupancy rate of the hotel in 2015.

\subsection{Hotel energy model calibration}

With collected information and the measurement of energy consumption $\left(302 \mathrm{kWh}_{\mathrm{pe}} / \mathrm{m}^{2}\right)$ it was developed the building energy model and the models is calibrated for electricity, gas and water consumption in 2015, according with criteria for MBE (2) and CV(RMSE) (3) [18], table 4. The electricity consumption follows closely the outdoor temperature on a daily basis showing the exposure to climate. In figure 8 is shown the energy consumption by use type.

$$
\begin{array}{r}
M B E=\frac{\sum_{i=1}^{N_{p}}\left(M_{i}-S_{i}\right)}{\sum_{i=1}^{N_{p}} M_{i}} \\
\operatorname{CV}(\text { RMSE })_{p}=\frac{\sqrt{\sum_{i=1}^{N_{p}}\left(M_{i}-S_{i}\right)^{2} / N_{p}}}{\sum_{i=1}^{N_{p}} M_{i} / N_{p}}
\end{array}
$$

\begin{tabular}{|c|c|c|}
\hline Criteria & $\begin{array}{c}\text { Hourly } \\
10 \% \leq \text { MBE } E_{h o u r l y} \leq 10 \% \\
\text { CV(RMSE)hourly } \leq 30 \%\end{array}$ & $\begin{array}{c}\text { Monthly } \\
-5 \% \leq \text { MBE }_{\text {monthy }} \leq 5 \% \\
\text { CV(RMSE)monthy } \leq 15 \%\end{array}$ \\
\hline Electricity & $\begin{array}{c}\text { MBE }_{\text {hourly }}=2 \% \\
\text { CV(RMSE })_{\text {hourly }}=20 \%\end{array}$ & $\begin{array}{c}\mathrm{MBE}_{\text {monthy }}=2 \% \\
\mathrm{CV}(\mathrm{RMSE})_{\text {monthly }}=11 \%\end{array}$ \\
\hline Gas & na & $\begin{array}{c}\mathrm{MBE}_{\text {monthy }}=3 \% \\
\mathrm{CV}(\mathrm{RMSE})_{\text {monthly }}=15 \%\end{array}$ \\
\hline Water & na & $\begin{array}{c}\text { MBE }_{\text {monthy }}=1 \% \\
\text { CV(RMSE) })_{\text {monthly }}=12 \%\end{array}$ \\
\hline
\end{tabular}

Table 4: Assessment of calibration criteria.

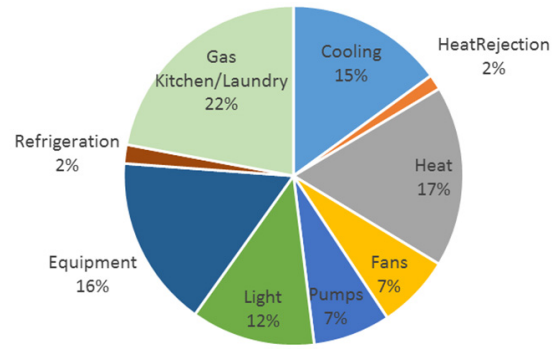

Figure 8: Energy consumption by use type. 


\subsection{Base case results}

With the previous calibrated building energy model and with weather data files from of Lisbon (2008 to 2015) and for TRY (epw_1990) and epw files of 2000 (epw_2000) and 2013 (epw_2013) the impact of different weather on the energy performance of the building was assessed. The simulation was also repeated for the climate change scenarios RCP 8.5 in 2080 with the morphing technique specified in section 2.2. For the base case (left side of figure 9) it's shown that using the building with weather data from 2008 to 2015 the average primary energy demand for cooling is $100.9 \mathrm{kWh}$ pe $\mathrm{m}^{2}$ and similar to the value of year 2010 . With the climate change scenarios an increase of $25 \%\left(25.2 \mathrm{kWh} / \mathrm{m}^{2}\right)$ in primary energy due to cooling is expected. For heating with gas it's expected a decrease of $10 \%\left(10 \mathrm{kWh}_{\mathrm{p}} / \mathrm{m}^{2}\right)$. The climate conditions in the period 2008 to 2015 introduce a small variability in the primary energy consumption of $3 \%$.

If the building envelope and HVAC are improved (see table 1) with thermal insulation of building envelop and pipes, solar collectors, chiller heat recovery and a change in indoor temperature set-points $\left(20-25^{\circ} \mathrm{C}\right.$ instead of $\left.21-23^{\circ} \mathrm{C}\right)$, the energy consumption is lower (right side of figure 9). Although these improvements, the impact of climate change is $32 \%\left(+19.9 \mathrm{kWh}_{\mathrm{pe}} / \mathrm{m}^{2}\right)$ due to cooling increase, greater than in the base case. In the following section are tested several changes in the base case to understand the changes and the effectiveness of adaptation strategies.

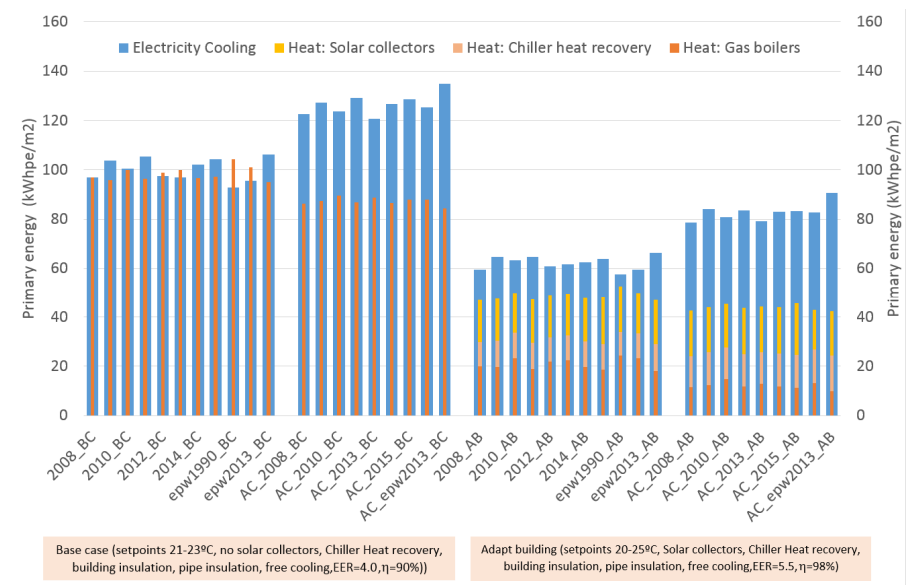

Figure 9: Primary energy demand of the base case and new construction.

\subsection{Sensitive analysis and impact of adaptation strategies}

The sensitive analysis was developed, starting with the base case and introducing discrete changes until a more performant building is obtained. The test cases are identified in table 1 , results in figure 10 and the main findings are: 
- $\quad$ Free cooling of 2 ach in rooms (case 2), free cooling and external shading (case 3 ) and cool wall and cool roof (case 4) have a small impact in the energy performance of building. Free cooling with 4 and 8 ach have also a small impact (cases 15, 16, 17).

- Thermal insulation of walls and roof without free cooling (case 5), with free cooling (case 6), and with external shading (case 7) have a small impact on energy performance, because there are shadows from other buildings and glass with a low solar factor.

- Increase pipe thermal insulation to $25 \mathrm{~mm}$ (case 8) instead of $15 \mathrm{~mm}$, reduces the heating and cooling energy.

- The upgrade of taps and showers to reduce the water (hot water) consumption to $150 \mathrm{l} /$ gn (actual consumption nearly $300 \mathrm{l} / \mathrm{g} . \mathrm{n}$ [19]) has an important impact on heating energy consumption (cases 9 and 12).

- Set point regulation to $20-25^{\circ} \mathrm{C}$ (cases 10 and 13) has an important impact in heating and cooling demand, as the use of more efficient chillers and boilers (case 11 vs. 6).

- The use of solar collector $2 \mathrm{~m}^{2} /$ room, chiller with heat recovery (case 11 ), halves the fossil fuel consumption for heating of case 6 . PV in the remaining roof and southwest façade has a small impact due to shadows.

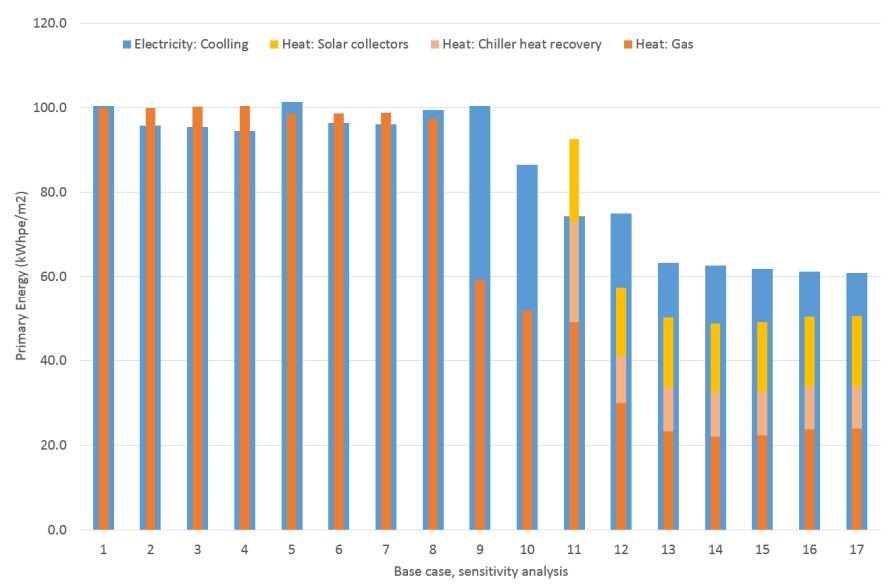

Figure 10: Sensitivity analysis.

\section{Conclusions}

Climate change has a dual implication on the built environment: on one hand human settlements and buildings are vulnerable to the effects of changing climate and on the other hand the building sector has a significant climate change mitigation potential [9]. The case study of a hotel in Lisbon, in the most severe scenarios of CC shows a potential increase of the primary energy for cooling load of $25 \%\left(25 \mathrm{kWh}\right.$ pe $\left./ \mathrm{m}^{2}\right)$ and a decrease of the heating load of $10 \%\left(10 \mathrm{kWh}_{\mathrm{pe}} / \mathrm{m}^{2}\right)$. 
To improve building resilience to $\mathrm{CC}$ there are non-climate factors such as better management of the set point that could reduce the cooling and heating load, perhaps education to tourists could also be important to explain the importance of an appropriate selection of set points. To reduce the building vulnerability, it was identified the importance of a rational use of hot water with efficient fittings and replace fossil fuel with heat recovery and solar collectors. Pipe insulation prove to have a positive impact to improve efficiency, greater than building envelope insulation, because this building have low solar factor windows, have shadows and a reasonable thermal insulation in walls and a roof with an attic space. Due to the shape of this building a completely passive behaviour is not assured and the, and several tested solutions have a low impact in cooling demand. This existing building have zones with high efficient light, low energy consumption ventilation and boilers with acceptable efficiency.

\section{Nomenclature}

g.n, guest night p.n, person night

$\mathrm{kWh}_{\text {pe }}, \mathrm{kWh}$ of primary energy (factor 2.5 for electricity 1.0 gas)

NZEB, Nearly Zero Energy Buildings epw, energy plus weather file

TRY, test reference year

$\mathrm{CC}$, Climate change

MBE, mean bias error

CV(RMSE), Coefficient of variation of RMSE

RCP, Representative Concentration Pathways

HVAC, heating ventilation and air conditioning

\section{Acknowledgements}

The authors wish to acknowledge all hotels partners of project AdaPT AC:T. The research presented in this paper has been funded by Programa AdaPT, from Agência Portuguesa do Ambiente, IP (APA, IP), as manager of the Portuguese Carbon Fund (FPC). The project is co-financed $85 \%$ by the EEA Grants and $15 \%$ by the FPC.

\section{References}

[1] EPBD-recast, "Diretiva para Eficiencia energética de edifícios." Comissão Europeias, Jornal Oficial, Bruxelas, 2010.

[2] A. Pinto et al., "Assessing climate change impact in hospitality sector. Simplified approach using building resources consumption signature," in 8th AECEF Symposium, New Actions and Roles of Civil Engineers: Sustainability and Energy, 2015.

[3] UNWTO, "Climate Change and Tourism - Responding to Global Challenges." World Tourism Organization and the United Nations Environment Programme, Madrid, 2008. 
[4] "Nearly Zero Energy Hotels." [online]. Available: http://www.nezeh.eu/ home/index.html.

[5] D. H. W. Li et al., "Impact of climate change on energy use in the built environment in different climate zones - A review," Energy, vol. 42, no. 1, pp. 103-112, 2012.

[6] F. D. Santos et al., Climate change in Portugal Scenarios, impacts and adaptation measures - SIAM: Executive summary and conclusions. Lisboa: Gradiva, 2001.

[7] H. Wang and Q. Chen, "Impact of climate change heating and cooling energy use in buildings in the United States," Energy Build., vol. 82, pp. 428-436, Oct. 2014.

[8] D. A. Asimakopoulos et al., "Modelling the energy demand projection of the building sector in Greece in the 21st century," Energy Build., vol. 49, pp. 488-498, Jun. 2012.

[9] S. Hrabovszky-Horváth et al., "Generalized residential building typology for urban climate change mitigation and adaptation strategies: The case of Hungary," Energy Build., vol. 62, pp. 475-485, 2013.

[10] IPCC, Summary for Policymakers. In Climate Change 2013: The Physical Science Basis. Contribution of Working Group I to the Fifth Assessment Report of the Intergovernmental Panel on Climate Change. Cambridge: Cambridge University Press, Cambridge, United Kingdom and New York, USA, 2013.

[11] F. Espírito Santo et al., "Trends in seasonal surface air temperature in mainland Portugal, since 1941," Int. J. Climatol., vol. 34, no. 6, pp. 1814 1837, 2014.

[12] A. Ramos et al., "Evolution of extreme temperatures over Portugal: recent changes and future scenarios," Clim. Res., vol. 48, pp. 177-192, 2011.

[13] M. F. Jentsch et al., "Climate change future proofing of buildingsGeneration and assessment of building simulation weather files," Energy Build., vol. 40, no. 12, pp. 2148-2168, 2008.

[14] RECS-E, "Regulamento de desempenho energético dos edifícios de comércio e serviços (RECS) - Requisitos de conceção para edifícios novos e intervenções." INCM. Portaria n. ${ }^{\circ}$ 349D-2013, alterada pela Portaria n. ${ }^{\circ}$ 17-A/2016, Lisboa, 2013.

[15] CIBSE TM55, Design for future climate : case studies. Londres: CIBSE, 2014.

[16] A. Pinto, "Pesquisa Bibliografica." LNEC. Projeto AdaPT., Lisboa, 2015.

[17] D. Styles et al., "Water management in the European hospitality sector: Best practice, performance benchmarks and improvement potential," Tour. Manag., vol. 46, pp. 187-202, 2015.

[18] Z. Yang and B. Becerik-Gerber, "A model calibration framework for simultaneous multi-level building energy simulation," Appl. Energy, vol. 149, pp. 415-431, 2015.

[19] A. Pinto et al., "Nexus água e energia em empreendimentos hoteleiros. Metodologia e resultados da aplicação em hotéis de 4 e 5 estrelas," in $13 .^{\circ}$ Congresso da água, 2016, pp. 1-12. 